POLITYKA ENERGETYCZNA - ENERGY POLICY JOURNAL

$2021+$ Volume $24 \uparrow$ Issue $4 \uparrow 89-104$

DOI: $10.33223 / \mathrm{epj} / 143043$

\author{
Svitlana Kalinina ${ }^{1}$, Olena LyndiuK ${ }^{2}$, Vasyl SavChenko ${ }^{3}$, Valeriya PodunaY ${ }^{4}$, \\ Svitlana LANSKA ${ }^{5}$, Eduard SAVCHENKO ${ }^{6}$
}

\title{
The development of renewable energy in the world in the context of employment transformation
}

ABSTRACT: This article is devoted to the worldwide development of renewable energy in connection to the development of the socio-economic system and employment transformations. It is emphasized that the use of renewable energy sources is growing extremely fast globally, and it is generating positive socio-economic effects such as creating jobs worldwide. It is noted that in contrast to the situation in the field of traditional energy, the number of vacancies in the field of renewable energy continues to grow; photovoltaic, bioenergy, hydropower and wind forms of renewable energy are powerful

$\triangle$ Corresponding Author: Valeriya Podunay; e-mail: vpodunay@gmail.com

${ }^{1}$ Theoretical and Applied Economics Department, Ukrainian State Employment Service Training Institute, Ukraine; ORCID iD: 0000-0002-2892-0410; e-mail: svitlana@skalinina.com.ua

2 Theoretical and Applied Economics Department, Ukrainian State Employment Service Training Institute, Ukraine; ORCID iD: 0000-0003-4503-5912; e-mail: lundyuk@ukr.net

3 Theoretical and Applied Economics Department, Ukrainian State Employment Service Training Institute, Ukraine; ORCID iD: 0000-0002-5836-1277; e-mail: savchenko.vasyl@gmail.com

4 Theoretical and Applied Economics Department, Ukrainian State Employment Service Training Institute, Ukraine; ORCID iD: 0000-0002-6314-156X; e-mail: vpodunay@gmail.com

5 Theoretical and Applied Economics Department, Ukrainian State Employment Service Training Institute, Ukraine; ORCID iD: 0000-0003-1986-8777; e-mail: sstomina@gmail.com

6 Theoretical and Applied Economics Department, Ukrainian State Employment Service Training Institute, Ukraine; ORCID iD: 0000-0002-7384-6029; e-mail: eds416@ukr.net

2021. The Author(s). This is an open-access article distributed under the terms of the Creative Commons Attribution-ShareAlike International License (CC BY-SA 4.0, http://creativecommons.org/licenses/by-sa/4.0/), which permits use, distribution, and reproduction in any medium, provided that the Article is properly cited. 
employers in the world economy. It is noted that the increase in the number of people employed in the field of renewable energy is a consequence of the decentralized nature of the sector, as a result of which, renewable energy technologies produce more vacancies per unit of investment compared to traditional electricity generation technologies. It has been emphasized that the further development of renewable energy depends on the volume of investment in the creation of production facilities, which contributes to the further creation of jobs. Furthermore, it has been determined that the problem of renewable energy staffing is also extremely relevant for Ukraine. It is noted that the current system of training for this energy sector does not meet the long-term requirements; the increase of energy efficiency and the development of renewable energy transform the qualification requirements for employees, which requires the transformation of approaches to the training and development of employees.

KEYWORDS: renewable energy, renewable energy employment, employment trends, energy transition investment

\section{Introduction}

The process of transformation to a model of sustainable development is based on the formation of the energy sector with a predominance of renewable energy sources, the use of which is growing extremely fast around the world. It is estimated that alternative energy sources will provide more than $40 \%$ of global demand by 2040 ("Alternative" employment 2020). According to the Global Roadmap REMap, developed by the International Renewable Energy Agency (IRENA 2020), the share of renewable energy in the energy sector should increase from $25 \%$ in 2017 to $85 \%$ in 2050 . By 2050, renewable energy sources may account for more than $60 \%$ of the total final consumption of many countries, which is 2.5 times higher than the current rate of renewable energy. For example, China is able to increase the share of renewable energy in its total energy consumption from $7 \%$ in 2015 to $67 \%$ in 2050 , and the EU's share may be increased from $17 \%$ to more than $70 \%$. The corresponding increase for India and the United States may be 2/3 (IRENA 2018).

Energy sector transformations cannot be considered to be independent from the socio-economic sphere. According to the Global Roadmap REMap, the transformation of the energy system will lead to positive socio-economic consequences: by 2050 there will be an increase in global welfare by $15 \%$, GDP growth by $1 \%$, employment growth by $0.1 \%$ (IRENA 2018). While employment growth in the world economy has slowed and in contrast to the situation in the field of traditional energy, the number of jobs in the field of renewable energy continues to grow, which requires adequate labor resources (Kalinina et al. 2019). 


\section{Employment trends in the renewable energy sector}

According to the International Renewable Energy Agency (IRENA), the renewable energy sector generates positive socio-economic effects by its activities, which leads to the creation of jobs in the industry worldwide (Fig. 1). There was a positive employment dynamic from 2012-2019. The number of jobs in the renewable energy sector in the world economy amounted to 11.46 million people in 2019 .

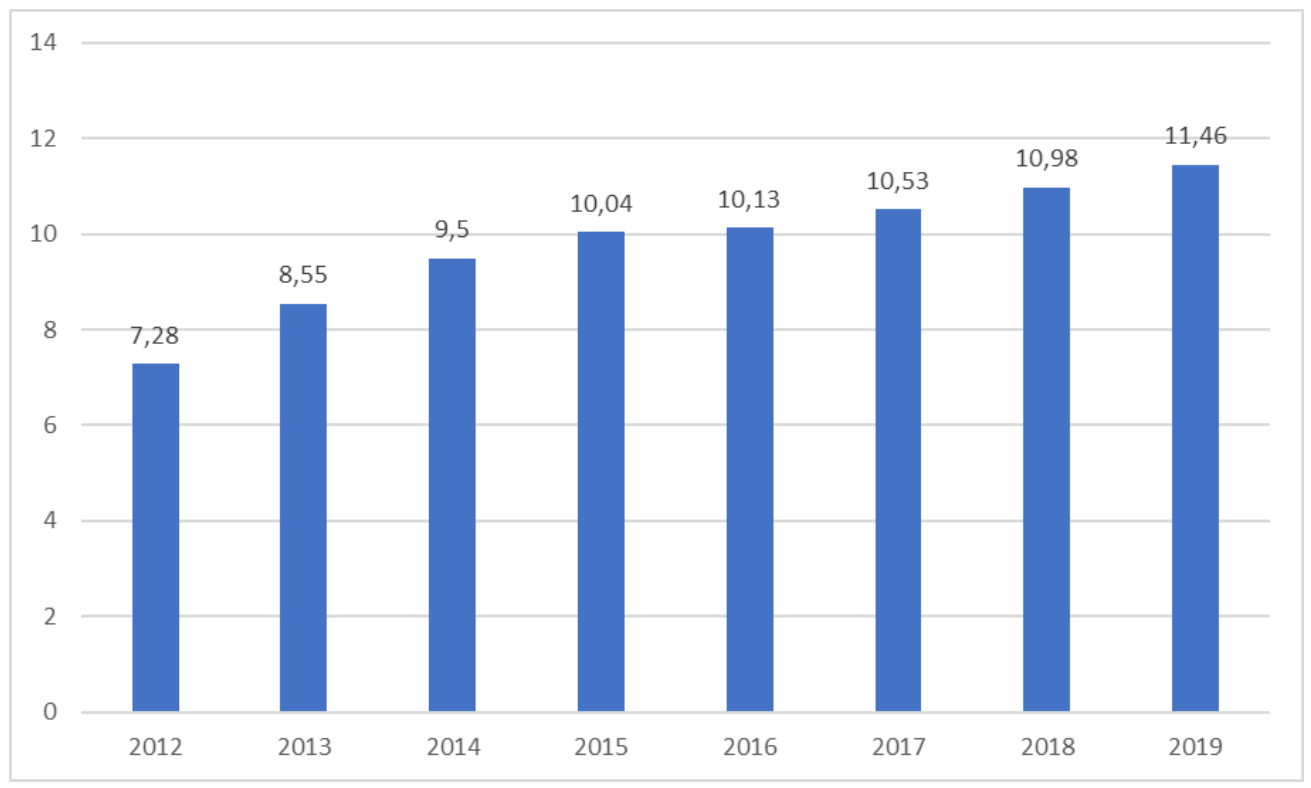

Fig. 1. Global renewable energy employment, 2012-2019 [jobs in thousands] Source: IRENA 2020

Rys. 1. Światowe zatrudnienie w energetyce odnawialnej, 2012-2019 [tys. miejsc pracy]

The main share of those employed in renewable energy was provided by the solar-energy sector -3.75 million jobs amounting to $33 \%$ of the total; 3.58 million settled in the bioenergy sector (of which 2.48 million relate to the biofuel sector), 1.96 million are in the hydropower sector and 1.17 million are in the wind-energy sector (Fig. 2, Table 1) (IRENA 2020).

According to IRENA, $87 \%$ of global employment in photovoltaic solar energy was concentrated in 10 countries in 2019 - China, Japan, USA, India, Bangladesh, Vietnam, Malaysia, Brazil, Germany and the Philippines (Fig. 3). In Ukraine, 25,000 people were employed in this sector. 


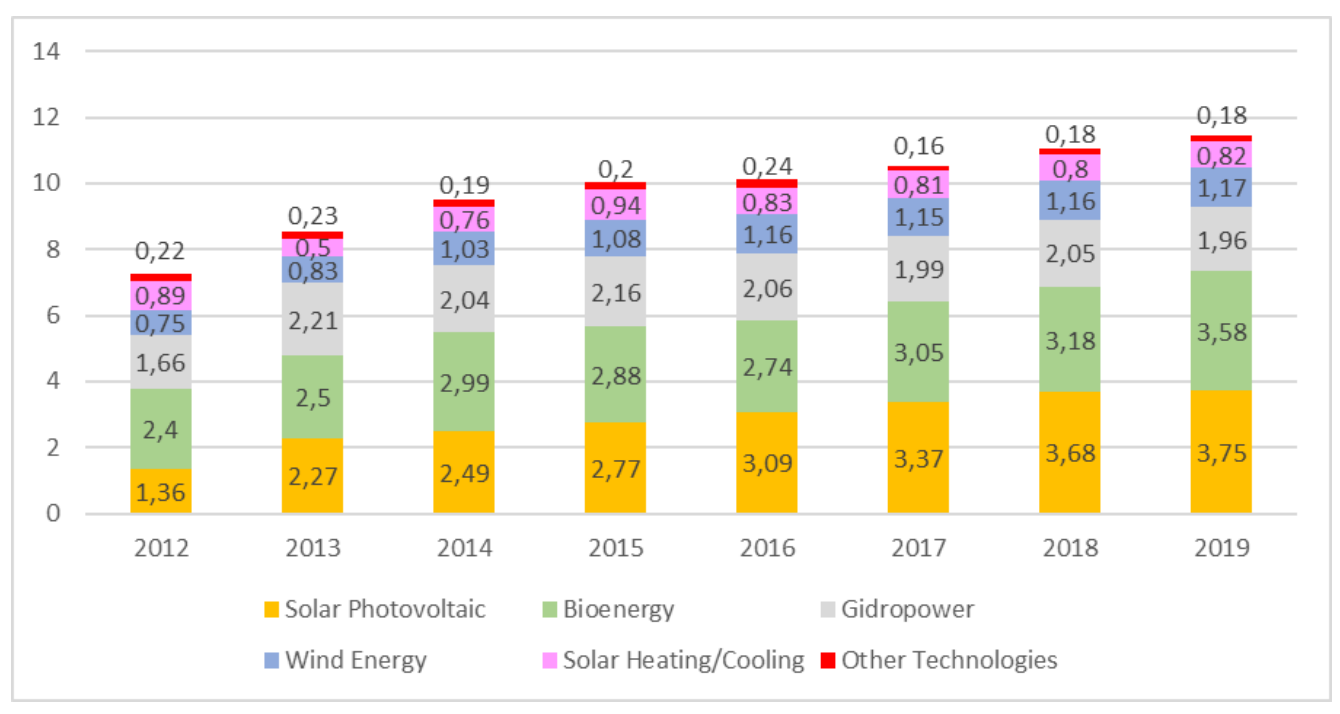

Fig. 2. Global renewable energy employment by technology, 2012-2019 [jobs in thousands] Source: IRENA 2020

Rys. 2. Global renewable energy employment by technology, 2012-2019 [tys. miejsc pracy]

TABLE 1. Global renewable energy employment by technology, 2019 [jobs in thousands]

TABELA 1. Światowe zatrudnienie w energetyce odnawialnej według technologii, 2019 [tys. miejsc pracy]

\begin{tabular}{|l|c|}
\hline \multicolumn{1}{|c|}{ Technology } & Thousand people \\
\hline All technologies & $11,458.5$ \\
\hline Solar Photovoltaic & $3,754.6$ \\
\hline Liquid Biofuels & $2,475.0$ \\
\hline Hydropower & $1,957.0$ \\
\hline Wind Energy & $1,165.3$ \\
\hline Solar Heating/Cooling & 822.8 \\
\hline Solid Biomass & 764.3 \\
\hline Biogas & 341.8 \\
\hline Geothermal Energy & 99.4 \\
\hline Municipal and Industrial Waste & 39.0 \\
\hline Concentrated Solar Power & 29.5 \\
\hline Other technologies & 8.6 \\
\hline Tide, Wave and Ocean Energy & 1.1 \\
\hline
\end{tabular}

Source: IRENA 2020. 


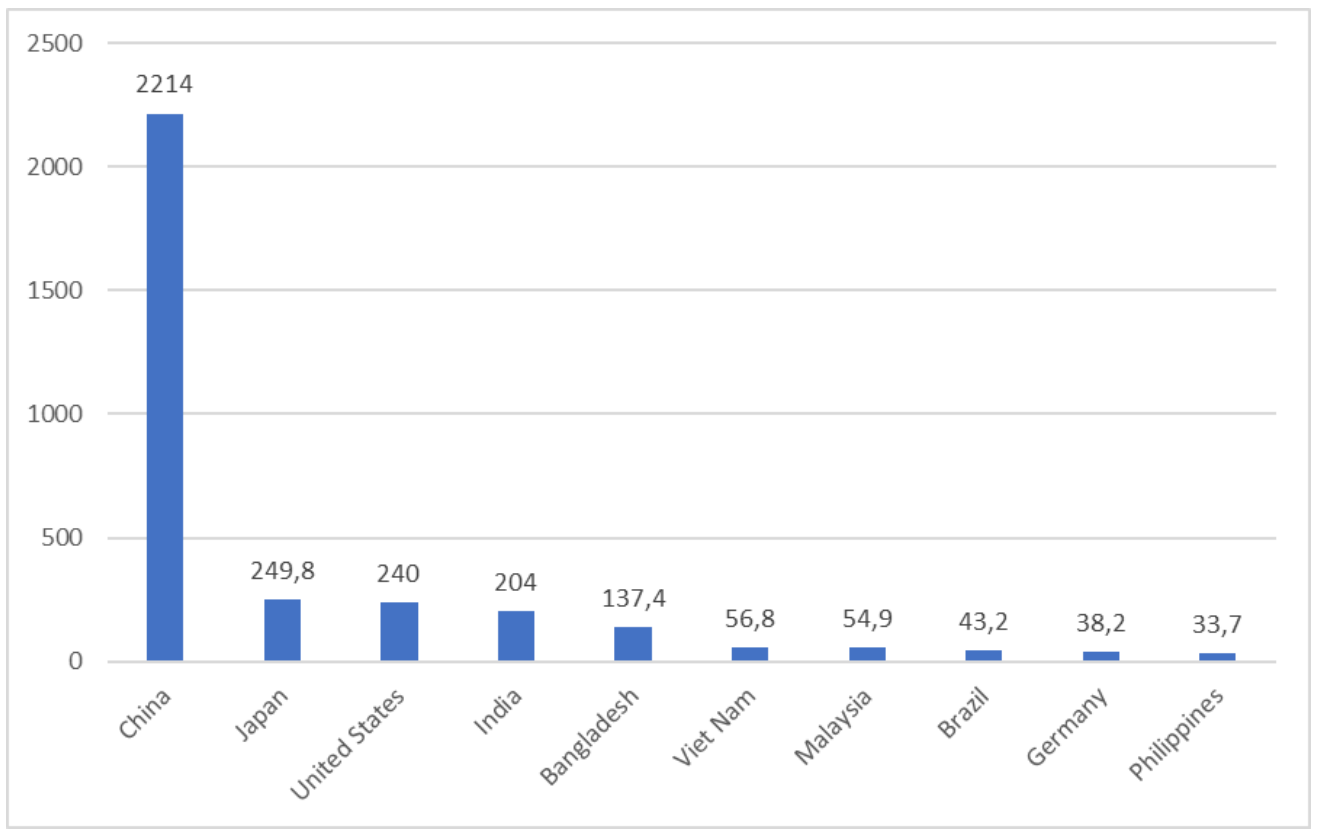

Fig. 3. Solar photovoltaic employment: top 10 countries, 2019 [jobs in thousands] Source: IRENA 2020

Rys. 3. Zatrudnienie w fotowoltaice: 10 największych krajów, 2019 [tys. miejsc pracy]

In the United States, for example, the number of job positions in photovoltaic solar energy has more than doubled over the last five years. Today, the number of people working in the field of solar energy is higher than in the field of oil and gas production and is almost three times higher than the number of people employed in coal production (UARE 2019). The employment increase in this area was facilitated by a policy of the importing of solar panels being replaced with theirproduction. Furthermore, employment increases arose from incentives introduced for the period 2006-2022 for easy loans to businesses and homeowners for them to install their own solar panels on their property.

Due to the growth of ethanol and biodiesel production, the number of job positions in the field of bioenergy increased to 2.5 million globally by 2019 (BP 2021). The leaders in biofuel production are Brazil, Indonesia, USA, Colombia, Thailand, Malaysia, China, Poland, Romania and the Philippines (Fig. 4). At the same time, the largest increase in employment was observed in countries with labor-intensive supply chains - Brazil, Colombia, Malaysia, Philippines and Thailand - while in the US and the EU, production declined (IRENA 2020).

Hydropower has the largest capacity of all the discussed energy sources. About two million people are employed in this sector worldwide. China, India, Brazil, Pakistan, Vietnam, the Russian Federation, Myanmar, Colombia, Turkey, and Canada are the leaders in terms of employment in this sector (Fig. 5). In Ukraine, the number of people employed in this sector is 


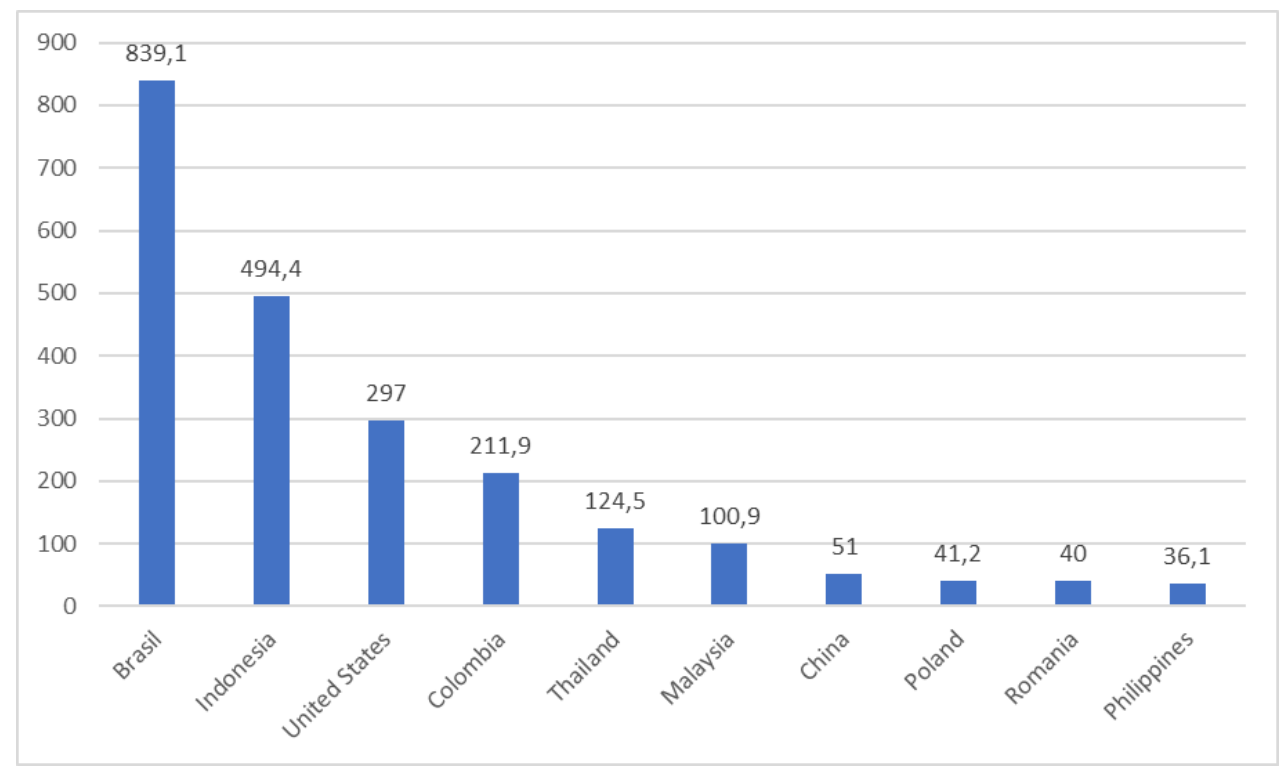

Fig. 4. Liquid biofuels employment: top 10 countries, 2019 [jobs in thousands] Source: IRENA 2020

Rys. 4. Zatrudnienie na biopaliwach ciekłych: 10 największych krajów, 2019 [tys. miejsc pracy]

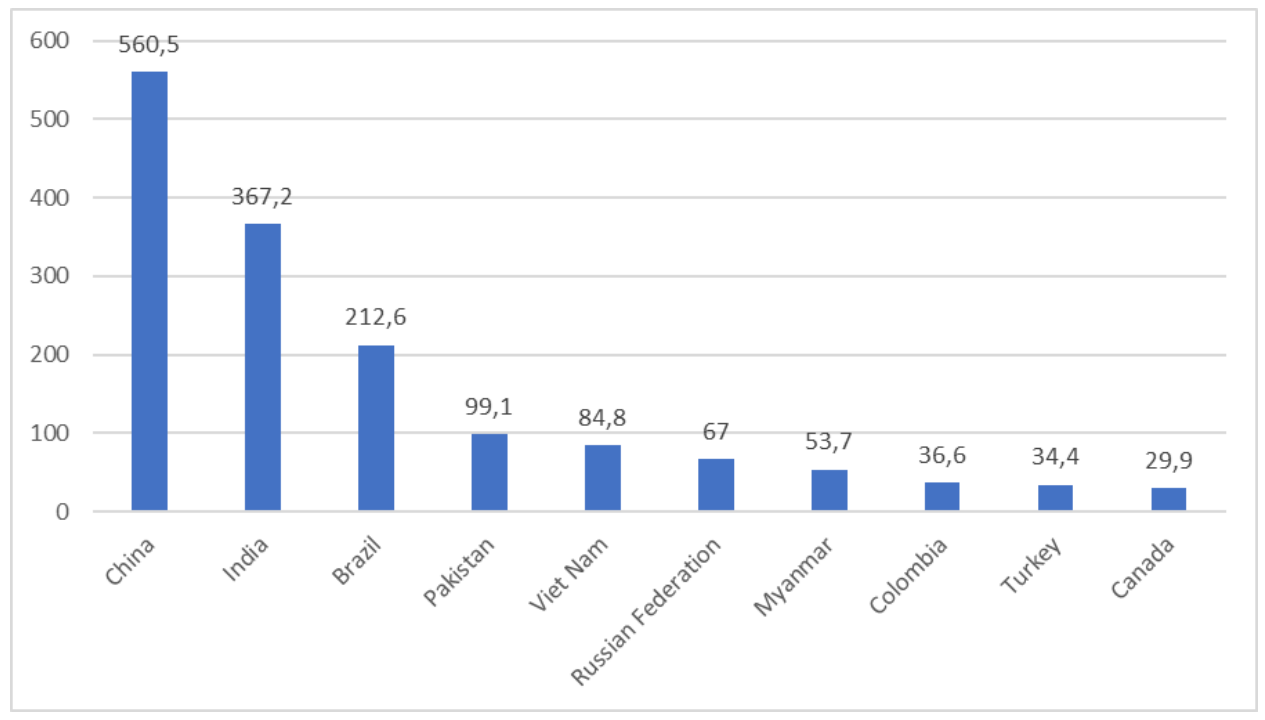

Fig. 5. Hydropower energy sector employment: top 10 countries, 2019 [jobs in thousands] Source: IRENA 2020

Rys. 5. Zatrudnienie w energetyce wodnej: 10 największych krajów, 2019 [tys. miejsc pracy] 
10.8 thousand people. At the same time, it should be noted that the growth rate of hydropower in the world is slowing down.

The number of people employed in the wind-energy sector is 1.2 million people globally. The largest increase in production capacity over the past ten years was observed in the coastal zone: the number of countries with onshore wind systems increased from 10 to 18 (IRENA 2020). Thus, in the Netherlands, the movement of railway trains is fully supplied by wind energy (UARE 2019).

Leaders in the production of wind energy in terms of employment are China, Germany, USA, India, Great Britain, Denmark, Mexico, Spain, the Philippines and Brazil (Fig. 6). The number of people employed in Ukrainian wind energy is nine thousand.

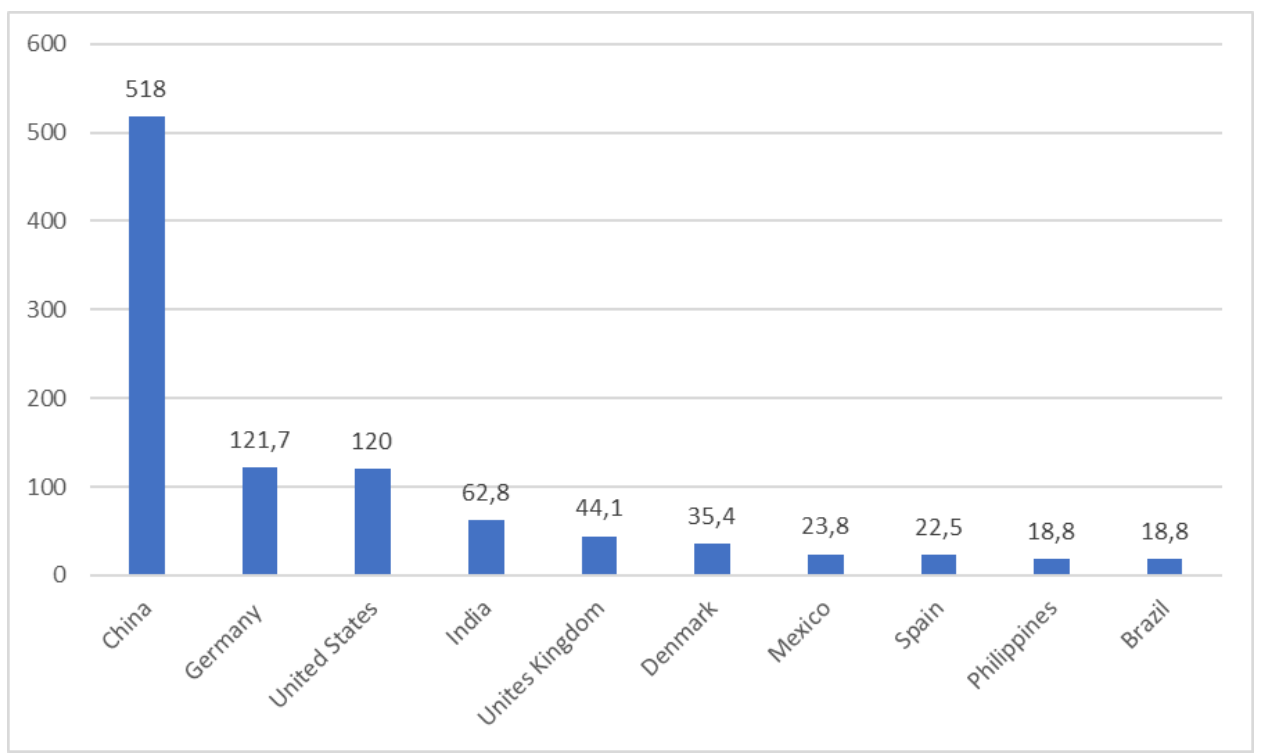

Fig. 6. Wind employment: top 10 countries, 2019 [jobs in thousands] Source: IRENA 2020

Rys. 6. Zatrudnienie w energetyce wiatrowej: 10 największych krajów, 2019 [tys. miejsc pracy]

Thus, the photovoltaic, bioenergy, hydropower and wind-energy sectors of renewable energy are powerful employers all over the world. In terms of the country, China, Brazil, India, the United States and the countries of the European Union are leaders in terms of the number of employees (Table 2). Renewable energy employs 309,000 people in Germany, 264,000 in Japan, 40,000 in South Africa and 28,000 in North Africa (IRENA 2020).

The world leader in the renewable energy sector in 2019 was Asia, which accounted for $63 \%$ of jobs, much of which are related to the supply chain of agricultural products, especially in countries such as Malaysia, Philippines and Thailand. The majority of jobs are held by men $-68 \%$, the share of jobs occupied by women is $32 \%$ (compared to $22 \%$ in the energy sector worldwide). 
TABLE 2. Estimated direct and indirect jobs in renewable energy worldwide by industry, 2019 [jobs in thousands]

TABELA 2. Szacowane bezpośrednie i pośrednie miejsca pracy w sektorze energii odnawialnej na całym świecie według przemysłu, 2019 [tys. miejsc pracy]

\begin{tabular}{|l|c|r|r|r|r|r|}
\hline & World & China & Brasil & India & USA & EU \\
\hline Solar Photovoltaic & 3,755 & 2,214 & 43 & 204 & 240 & 127 \\
\hline Liquid Biofuels & 2,475 & 51 & 839 & 35 & 297 & 239 \\
\hline Hydropower & 1,957 & 561 & 213 & 367 & 22 & 78 \\
\hline Wind Energy & 1,165 & 518 & 19 & 63 & 120 & 292 \\
\hline Solar Heating/Cooling & 823 & 670 & 44 & 23.8 & 5 & 36 \\
\hline Solid Biomass & 764 & 188 & & 58 & 51 & 392 \\
\hline Biogas & 342 & 145 & & 85 & 7 & 75 \\
\hline Geothermal Energy & 99.4 & 3 & & & 9 & 40.6 \\
\hline Concentrated Solar Power & 29.5 & 11 & & & 5 & \\
\hline Total & 11,459 & 4,361 & 1,158 & 824 & 756 & 1,317 \\
\hline
\end{tabular}

Source: IRENA 2020

The share of women in STEM positions (science, technology, engineering and mathematics) is lower than in administrative positions (28\% vs. 45\%) (IRENA 2020).

The increase in the number of people employed in renewable energy is a consequence of the decentralized structure of the sector, which stimulates job creation in rural areas; the effect of increasing employment is observed in agriculture, the food industry, local trade, communications and healthcare.

\section{Investments in renewable energy development and its impact on employment}

The constant growth of demand for renewable energy sources is stimulated by markets, corporations, cities and communities, which constantly feel the need for low-cost, environmentally friendly and reliable energy sources (Deloitte 2018).

The further development of renewable energy will depend on the volume of investment in the production facilities' creation. If the volume of investments in the renewable energy development and related technologies amounts to 824 USD billion in 2019, then according to estimates, the annual need for investment during energy transformation will be about two trillion USD during 2021-2023 (Fig. 7), increasing to 4.5 trillion USD per year by 2030 (Table 3) (IRENA 2020). 


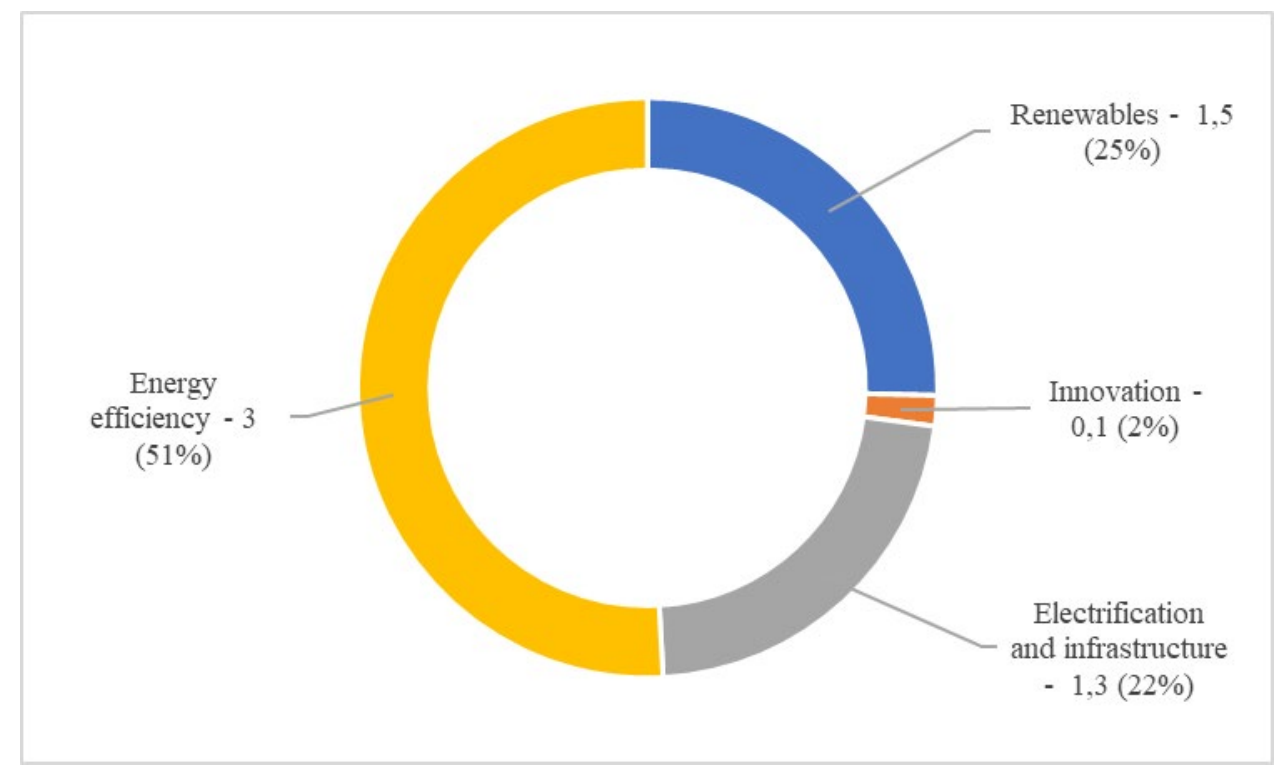

Fig. 7. Energy transition investment under the Transforming Energy Scenario, 2021-2023 [trillion USD and \%] Source: IRENA 2020

Rys. 7. Inwestycja w transformację energetyczną w ramach Scenariusza Transformacji Energetycznej, 2021-2023 [bln USD oraz \%]

According to the scenario of energy transformation, the main need for investment ( $\$ 5.9$ billion during the period 2021-2023) will be demonstrated by the countries of East Asia - 32\%, North America - 18\%, the European Union together with the United Kingdom - $12 \%$, the remaining Asian countries - 12\% (Fig. 8).

Investments in the energy sector help in job creation. According to the US Department of Energy, renewable energy technologies produce more vacancies per USD of investment compared to traditional electricity generation technologies ("Alternative" employment 2020): USD one million of investment in the production of renewable energy sources creates at least twenty-five vacancies, for energy efficiency development - 10 vacancies. Globally, this means the creation of a total of about 5.5 million additional positions, of which 2.46 million vacancies will be in the renewable energy sector, 2.91 million will be in the field of energy efficiency, and 0.12 million will be in the field of electricity and infrastructure by 2023 . However, there is due to be a much higher reduction of employees in the fossil fuel and nuclear energy sector - 1.07 million (IRENA 2020).

According to the REMAP roadmap, 7.4 million jobs will be lost in fossil fuels by 2050, but 19.0 million vacancies will be created in renewable energy, including energy efficiency, network modernization and energy system flexibility. In total, a net increase of 11.6 million jobs will be provided (IRENA 2018). At the same time, according to the University of California, Berkeley, each position in the field of solar energy creates from 1.8 to 2.8 jobs in other sectors of the economy ("Alternative" employment 2020). 
TABLE 3. New investment needs for renewable energy and grids by sector and technology group, annual averages, 2019-2030 [billion USD per year]

TABELA 3. Nowe potrzeby inwestycyjne w zakresie energii odnawialnej i w sieci w podziale na sektory i grupy technologiczne, średnie roczne, 2019-2030 [mld USD rocznie]

\begin{tabular}{|c|c|c|}
\hline & Sector and technology group & Average annual investments \\
\hline \multirow{19}{*}{ 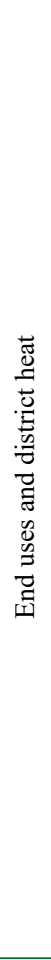 } & $\begin{array}{l}\text { District heat: } \\
\text { renewable heating, fuels (solar thermal, modern bioenergy etc.) }\end{array}$ & 18 \\
\hline & Industry & \\
\hline & $\downarrow$ Hydrogen electrolyzer & 20 \\
\hline & $\downarrow$ Renewables, direct uses & 34 \\
\hline & $\downarrow$ Heat pumps & 32 \\
\hline & $\downarrow$ Energy efficiency & 357 \\
\hline & Transport & \\
\hline & $\downarrow$ Biofuels, supply & 82 \\
\hline & $\downarrow$ Energy efficiency & 309 \\
\hline & $\downarrow$ Charging infrastructure for EVs & 261 \\
\hline & Buildings & \\
\hline & $\downarrow$ Renewables, direct uses & 25 \\
\hline & $\downarrow$ Heat pumps & 90 \\
\hline & $\downarrow$ Energy efficiency & 2072 \\
\hline & Grids & \\
\hline & $\downarrow$ Battery storage & 20 \\
\hline & $\downarrow$ Pumped hydro & 16 \\
\hline & $\downarrow$ Smart meters & 20 \\
\hline & $\downarrow$ Grids & 279 \\
\hline \multirow{9}{*}{$\begin{array}{l}\overline{0} \\
\text { ò } \\
0\end{array}$} & Generation capacity & \\
\hline & $\downarrow$ Marine and others & 20 \\
\hline & $\downarrow$ Geothermal & 18 \\
\hline & $\downarrow$ Wind, offshore & 66 \\
\hline & $\downarrow$ Wind, onshore & 273 \\
\hline & $\downarrow$ Concentrating solar power & 23 \\
\hline & $\downarrow$ Solar photovoltaic & 318 \\
\hline & $\downarrow$ Bioenergy & 76 \\
\hline & $\downarrow$ Hydro (excl. pumped) & 55 \\
\hline
\end{tabular}

Source: IRENA 2020.

In the European Union, there is expected to be an increase in employment in the sector of equipment production due to creation of the European Solar Manufacturing Council (ESMC) (EC 2019). According to estimates of the European Solar Energy Association Solarpower Euro- 


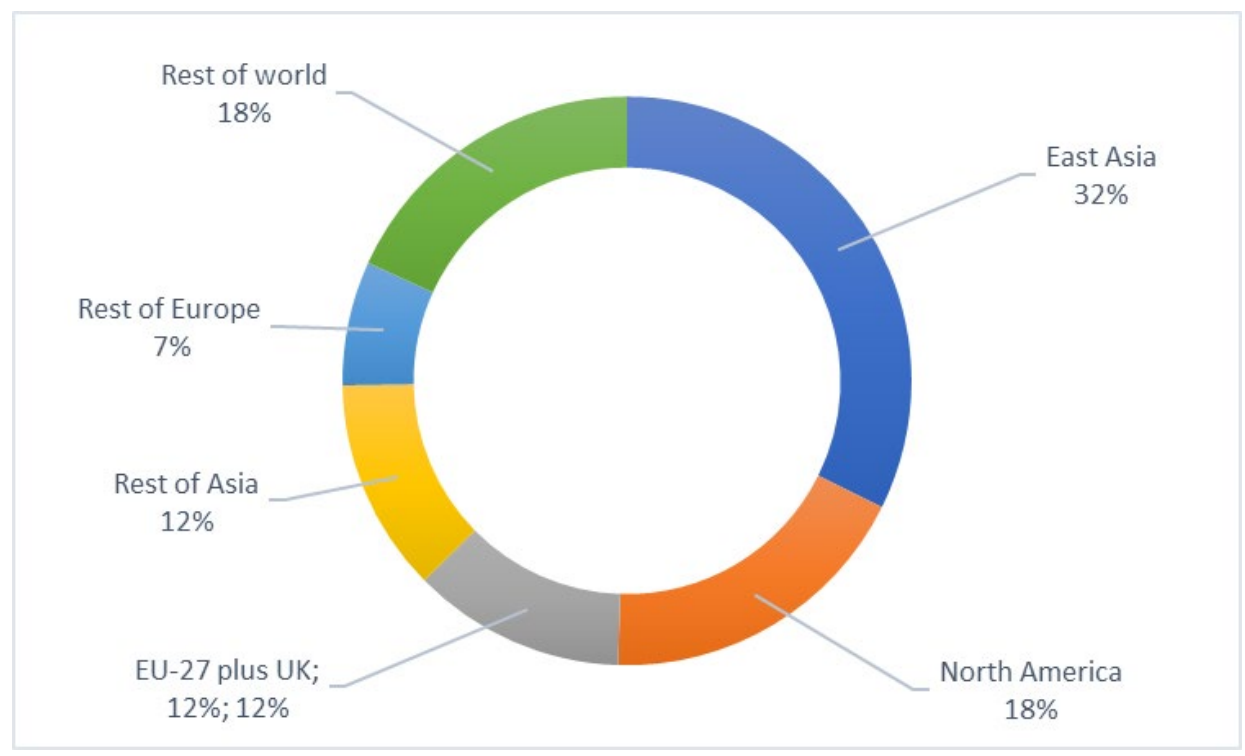

Fig. 8. Average annual investments in clean energy under the Transforming Energy Scenario, annual averages, 2019-2030 [\%]

Source: IRENA 2020

Rys. 8. Inwestycje w czystą energię w ramach Scenariusza Transformacji Energetycznej, średnie roczne, 2019-2030 [\%]

pe, the implementation of appropriate industrial policies in this area could increase employment in solar generation in the EU to 300 thousand people ("Alternative" employment 2020).

Thus, in the electricity industry of many countries, there are significant changes, the purpose of which is to provide access to inexpensive, reliable, permanent and modern energy sources for all humanity (US Office of Electricity 2020).

\section{Staffing for the development of renewable energy}

The energy transformation, the objective of which is to increase energy efficiency and energy use of renewable and alternative sources, not only changes energy-production technology but also increases the staff needs of the energy sector (Fig. 9). According to the reference scenario, it is expected that in the energy sector, 68.2 million people will be employed by 2030 , according to the scenario of the REmap roadmap - 85.0 million people, by 2050 (IRENA 2018).

Increasing energy efficiency and the renewable energy development transform the qualification requirements for employees. The current system of training for renewable energy does not 
meet the long-term requirements. To solve this problem, many countries have created their own training centers and programs. Thus, the universities of Brazil, Canada, China, Cuba, Denmark, and Egypt have created a decentralized network to provide training and implement postgraduate training programs. Another example is the Mediterranean Renewable Energy Center (MEDREC), established by the governments of Italy and Tunisia (MEDREC 2021) to train, disseminate knowledge and information, create educational networks and develop renewable energy projects in the region (partners: Algeria, Egypt, Libya, Morocco, Tunisia).

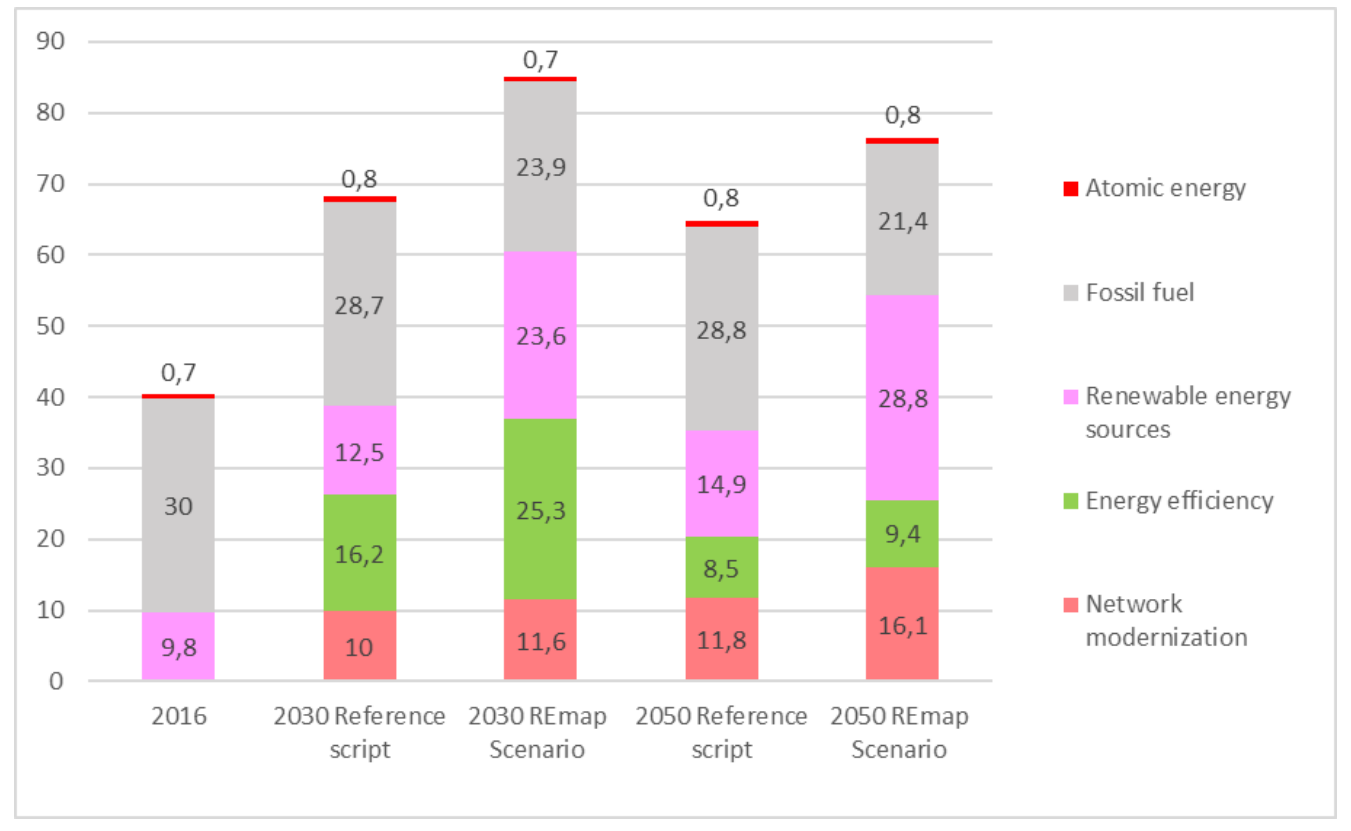

Fig. 9. Job creation in the global energy sector by 2050 [jobs in millions] Source: IRENA 2018

Rys. 9. Tworzenie miejsc pracy w światowej energetyce do 2050 r. [mln miejsc pracy]

Other examples of competence-building and know-how transfer initiatives for the wind and solar sectors should also be mentioned: Energy Sector Management Assistance Program (ESMAP 2021), Technology Needs Assessment Project (TNA 2021), Africa-EU Energy Partnership (AEEP 2021), Renewable Energy Research for Global Markets (REnKnow.Net 2021), Asia-Pacific Network for Global Change Research (APN 2021), Solar Facilities for the European Research Area (SFERA 2021), etc.

The problem of renewable energy staffing is also extremely relevant for Ukraine. The government approved the National Renewable Energy Action Plan in 2014. This document provides an increase in the share of renewable sources in the overall balance of electricity generation in the country to $11 \%$ by 2020 , and up to $25 \%$ ("Alternative" employment 2020) by 2035 . 
During the period 2012-2019, 45,000 people were employed in solar and wind energy in Ukraine (Tkachuk 2020). According to the European-Ukrainian Energy Agency, the shortage of qualified personnel is felt by $89.2 \%$ of companies, and $67.6 \%$ of these companies assessed the shortage of qualified personnel as "a very significant shortage of staff" ("Alternative" employment 2020).

The amount of state orders for the training of specialists in the energy sector during the period 2012-2019 reduced (Table 4), while the quality of training, as a rule, does not satisfy employers, who mainly emphasize the theoretical nature and obsolescence of the acquired knowledge (Lanska and Mishchenko 2020). In order to meet the needs of the renewable energy sector in human resources, the principles of education and training must meet the latest qualification requirements for employees. As a result, about $90 \%$ of Ukrainian companies invest their own funds in staff training ("Alternative" employment 2020).

TABLE 4. Volume of the state order for the training of specialists of energy specialties (specialists) in Ukraine, 2012-2019 [persons]

TABELA 4. Zamówienia publiczne na szkolenia w zakresie specjalności energetycznych na Ukrainie, 2012-2019 [osoby]

\begin{tabular}{|c|c|c|c|c|c|c|c|c|c|c|c|c|c|c|c|c|}
\hline \multirow[b]{2}{*}{ Specialty } & \multicolumn{2}{|c|}{2012} & \multicolumn{2}{|c|}{2013} & \multicolumn{2}{|c|}{2014} & \multicolumn{2}{|c|}{2015} & \multicolumn{2}{|c|}{2016} & \multicolumn{2}{|c|}{2017} & \multicolumn{2}{|c|}{2018} & \multicolumn{2}{|c|}{2019} \\
\hline & 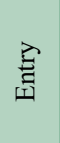 & 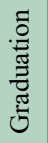 & 氞 & 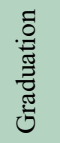 & 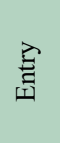 & 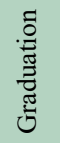 & 氙 & 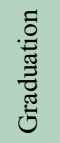 & 氙 & 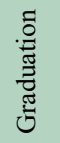 & 㲄 & 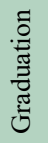 & 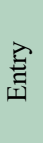 & 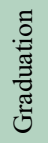 & 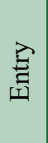 & 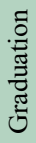 \\
\hline Heat energy & 716 & 0 & 591 & 789 & 559 & 524 & 362 & 453 & 2 & 336 & 0 & 46 & 0 & 0 & 0 & 0 \\
\hline Thermal power plants & 253 & 0 & 179 & 248 & 202 & 174 & 165 & 166 & 0 & 153 & 0 & 36 & 0 & 0 & 0 & 0 \\
\hline Hydropower & 53 & 0 & 54 & 50 & 49 & 54 & 51 & 46 & 0 & 49 & 0 & 4 & 0 & 0 & 0 & 0 \\
\hline Atomic energy & 132 & 0 & 187 & 138 & 181 & 80 & 151 & 142 & 33 & 163 & 0 & 85 & 0 & 0 & 0 & 0 \\
\hline
\end{tabular}

Source: TNA 2021.

As part of the energy sector transformation, opportunities for further employment growth can be created by retraining fossil fuel sector workers who have significant skills and experience to maintain the quality of jobs created in the renewable energy sector. Relevant efforts should be focused on training, concluding the necessary training programs, using information and communication technologies, and developing public-private partnerships in the renewable energy sector (Kalinina et al. 2020). 


\section{Conclusions}

At present, the development of energy is characterized by a significant increase in the share and importance of renewable energy sources. Renewable energy has become the most important sector of the modern global economy. The growing share of renewable energy sources in the world energy balance has a positive effect on world GDP and welfare and leads to higher employment.

Renewable energy is currently one of the largest employers in the global economy. The number of people employed in this sector in the leading countries has exceeded the corresponding indicators of the coal and oil industries.

The development of renewable energy transforms the qualification requirements for employees. The current system of training for this energy sector does not meet the long-term requirements, which are transformations of approaches to training and the development of employees.

\section{References}

"Alternative" employment 2020. Is the personnel market keeping up with the changes in the energy sector? («Alternativnaya» zanyatost. Uspevayet li rynok kadrov za izmeneniyami v sektore energetiki?) [Online] http://economica.com.ua/solnechnaia_enerhyia/article/alternatyvnaia_zaniatost.html [Accessed: 2021-07-16] (in Russian).

AEEP 2021. Africa-EU Energy Partnership. [Online] https://africa-eu-energy-partnership.org/ [Accessed: 2021-07-31].

APN 2021. Asia-Pacific Network for Global Change Research. [Online] https://www.apn-gcr.org/ [Accessed: 2021-07-29].

BP 2021. BP Statistical Review of World Energy, Edition 2021. [Online] https://www.bp.com/en/global/ corporate/energy-economics/statistical-review-of-world-energy.html [Accessed: 2021-08-17].

Deloitte 2018. International Renewable Energy Trends (Mezhdunarodnyye tendentsii v oblasti vozobnovlyayemykh istochnikov energii). Deloitte, Insights. Deloitte Development LLC. [Online] https:// www2.deloitte.com/content/dam/Deloitte/ru/Documents/energy-resources/Russian/global-renewable-energy-trends.pdf [Accessed: 2021-08-08] (in Russian).

EC 2019. Communication from the Commission to the European Parliament, the European Council, the Council, the European Economic and Social Committee and the Committee of the Regions "The European Green Deal”. European Commission. Brussels, 11.12.2019, COM(2019) 640 final.

ESMAP 2021. Energy Sector Management Assistance Program. [Online] https://www.esmap.org/ [Accessed: 2021-07-30].

IRENA 2018. Transformation of the global energy system. Roadmap to 2050 (Preobrazovaniye globalnoy energeticheskoy sistemy. Dorozhnaya karta do 2050). [Online] https://www.irena.org/-/media/ Files/IRENA/Agency/Publication/2018/Apr/IRENA_Global_Energy_Transformation_2018 summary_RU.pdf?la=en\&hash=65D7B55F58A18EFA01D7F0FB0A74DA691F9C57F9 [Accessed: 202107-21] (in Russian).

IRENA 2019. Renewable Energy Employment by Country. [Online]. https://www.irena.org/Statistics/ View-Data-by-Topic/Benefits/Renewable-Energy-Employment-by-Country [Accessed: 2021-08-17]. 
IRENA 2020. Global Renewables Outlook: Energy Transformation 2050. [Online] https://www.irena.org/-/ media/Files/IRENA/Agency/Publication/2020/Apr/IRENA_Global_Renewables_Outlook_2020.pdf [Accessed: 2021-08-01].

IRENA 2020. Renewable energy and jobs. 2020 Annual Review (Vozobnovlyayemaya energetika i rabochiye mesta. Ezhegodnyy obzor za 2020 g.) [Online] https://irena.org/-/media/Files/IRENA/Agency/Publication/2020/Sep/Key_Findings_Jobs_Review_2020_RU.pdf?la=en\&hash=DB49345C378E61214D197BA5FED1729AD36633F7 [Accessed: 2021-07-09] (in Russian).

IRENA 2020. Renewable Energy and Jobs. Annual Review 2020. IRENA. [Online]. https://www.irena.org/ publications/2020/Sep/Renewable-Energy-and-Jobs-Annual-Review-2020 [Accessed: 2021-08-08].

IRENA 2020. The Post-Covid Recovery. [Online] https://irena.org/-/media/Files/IRENA/Agency/Publication/2020/Jun/IRENA_Post-COVID_Recovery_2020.pdf [Accessed: 2021-07-30].

IRENA 2020. The quantity of jobs in the renewable energy sector continues to grow and totals 11.5 million worldwide (Kolichestvo rabochikh mest $v$ sektore vozobnovlyayemykh istochnikov energii prodolzhayet rasti $i$ naschityvayet $11.5 \mathrm{mln}$ po vsemu miru). [Online] https://www.irena.org/-/media/Files/IRENA/Agency/Press-Release/2020/Sep/PRESS-RELEASE--Jobs-Russian.pdf?la=en\&hash=527ACF3DE078EC9EEAAACC452469DCB61861FDA4 [Accessed: 2021-07-14] (in Russian).

Kalinina et al. 2019 - Kalinina, S., Mikhaylushin, L., Korovchuk, Y. and Kushnarenko, O. 2019. Monitoring of International Labor Migration in the Context of the World Economy Labour Resources Providing Problems. Advances in Economics, Business and Management Research (MDSMES) 99. Atlantis Press. 2019, pp. 389-392, DOI: 10.2991/mdsmes-19.2019.74.

Kalinina et al. 2020 - Kalinina, S., Lyndiuk, O. and BuchyK, V. 2020. Development of renewable energy in Ukraine in the context of ensuring public employment. Polityka Energetyczna - Energy Policy Journal 23(4), DOI: 10.33223/epj/130319.

LAnska, S. and Mishchenko, S. 2020. Theoretical And Methodological Aspects Of Labor Market Development Under The Influence Of Destabilizing Factors. Norwegian Journal of development of the International Science 50(3), pp. 38-45.

MEDREC 2021. Cooperation, efficiency, and Innovation for sustainability in the Mediterranean. [Online] https://www.medrec.org/about [Accessed: 2021-07-29].

REnKnow.Net 2021. Renewable Energy Research for Global Markets REnKnow.Net. [Online] http://renknow.net/ [Accessed: 2021-07-29].

SFERA 2021. Solar Facilities for the European Research Area. [Online] https://sfera.sollab.eu/ [Accessed: 2021-07-29].

TкаснUк, Y. 2020. Personnel for the power industry: what do power companies think about professional education in Ukraine (Kadry dlya energetiki: chto dumayut energokompanii o professionalnom obrazovanii v Ukraine). [Online] https://kosatka.media/category/blog/news/kadry-dlya-energetiki-chto -dumayut-energokompanii-o-professionalnom-obrazovanii-v-ukraine [Accessed: 2021-08-09] (in Russian).

TNA 2021. Technology Needs Assessment - UNEP DTU Partnership. [Online] https://tech-action.unepdtu. org/ [Accessed: 2021-07-30].

UARE 2019. Renewable energy: a chance for employment growth in Ukraine (Vozobnovlyayemaya energetika: shans dlya rosta zanyatosti v Ukraine) [Online] https://uare.com.ua/ru/novyny/556-vozobnovlyaemaya-energetika-shans-dlya-rosta-zanyatosti-v-ukraine.html [Accessed: 2021-07-21] (in Russian).

US Office of Electricity 2020. Grid Modernization and Smart Grid. [Online] https://www.energy.gov/oe/ activities/technology-development/grid-modernization-and-smart-grid [Accessed: 2021-07-21]. 


\section{Svitlana Kalinina, Olena Lyndiuk, Vasyl Savchenko, Valeriya Podunay, \\ Svitlana LANSKA, Eduard SAVCHENKO}

\section{Rozwój energetyki odnawialnej na świecie w kontekście zmian zatrudnienia}

\section{Streszczenie}

Artykuł poświęcony jest światowemu rozwojowi energetyki odnawialnej w kontekście zmian systemu społeczno-gospodarczego i zatrudnienia. Podkreśla się, że wykorzystanie odnawialnych źródeł energii na świecie rośnie niezwykle szybko i generuje pozytywne efekty społeczno-gospodarcze, takie jak tworzenie miejsc pracy na całym świecie. Zauważa się, że w przeciwieństwie do sytuacji w dziedzinie energetyki tradycyjnej, liczba wolnych miejsc pracy energetyce odnawialnej stale rośnie; fotowoltaika, bioenergia, energia wodna $\mathrm{i}$ wiatrowe formy energii odnawialnej są potężnymi pracodawcami w gospodarce światowej. Zwraca się uwagę, że wzrost liczby osób zatrudnionych w obszarze OZE jest konsekwencją zdecentralizowanego charakteru sektora, w wyniku którego technologie OZE wytwarzają więcej miejsc pracy na jednostkę inwestycji w porównaniu z tradycyjnymi technologiami wytwarzania energii elektrycznej. Podkreślono, że dalszy rozwój energetyki odnawialnej zależy od wielkości inwestycji w tworzenie zakładów produkcyjnych, co przyczynia się do dalszego tworzenia miejsc pracy. Ponadto ustalono, że problem zatrudnienia w energetyce odnawialnej jest niezwykle istotny również dla Ukrainy. Zauważa się, że obecny system szkoleń dla tego sektora energetycznego nie spełnia wymagań w długim terminie; wzrost efektywności energetycznej i rozwój energetyki odnawialnej zmieniają wymagania kwalifikacyjne stawiane pracownikom, co wymaga zmiany podejścia do szkolenia i rozwoju pracowników.

SŁowa KLUCZowe: energia odnawialna, zatrudnienie w energetyce odnawialnej, trendy w zatrudnieniu, inwestycje w transformację energetyczną 